\title{
MONACO RADIOCARBON MEASUREMENTS III
}

\section{J. THOMMERET and Y. THOMMERET}

Centre Scientifique de Monaco

The following list of dates contains most of the measurements obtained since our last list. Procedures of measurements and calculation are as previously described in Radiocarbon, 1964, v. 6, p. 194-196; 1966, v. 8, p. 286-291. A new $1.1 \mathrm{~L}$ counter, all metal and quartz, built in the laboratory has been in use since 1967 .

We acknowledge the help of Miss G. Hugues in preparing chemical samples and all submitters for their comments.

\section{SAMPLE DESGRIPTIONS}

I. GEOLOGIC SAMPLES

Measurements are devoted to contributions in Mediterranean Sea sediment deposits, sea-level changes and shore processes.

\section{Etang de Thau sediment series, France}

A piston core, $2 \mathrm{~m}$ long, taken in Etang de Thau (Hérault) $\left(43^{\circ} 26^{\prime}\right.$ N Lat, $3 \circ 38^{\prime}$ E Long), in water $8 \mathrm{~m}$ deep. Coll. and subm. 1966 by $\mathrm{B}$. Chassefière, Centre de Sédimentologie Marine, Perpignan, Hérault. Sediment sample comes from one of several approx. circular shell mounds (cadoules), peculiar to bottom of this coastal lake. Core consists of layers of shelly sands alternating with layers of mollusc shells filled with silt. Measurements were made on shells of mussels and of serpulid worms selected at particular levels.

$$
420 \pm 60
$$

\section{MC-169. Etang de Thau 1}

Upper layer 0 to $5 \mathrm{~cm}$. Fine shell debris (Mytilus sp.).

MC-170. Etang de Thau 2

$$
440 \pm 60
$$

Upper layer 0 to $5 \mathrm{~cm}$. Calcareous tubes of serpulid worms.

\section{MC-171. Etang de Thau 3}

85 to $90 \mathrm{~cm}$ layer. Coarse sand with fragments of shells of various molluscs. Dating on mixed shell fragments (Mytilus sp. and Serpula sp.).

MC-167. Etang de Thau 4

A.D. 1370

$$
580 \pm 90
$$

90 to $100 \mathrm{~cm}$ layer. Serpulid worms only.

$$
1290 \pm 80
$$

MC-166. Etang de Thau 5

\section{A.D. 660}

182 to $187 \mathrm{~cm}$ layer. Clayey silt. Dating on large shell fragments (Mytilus sp.).

General Comment (B.C.): sedimentologic as well as macro- and microfaunal studies indicate that during minor regression, general reworking 
took place in pond. Since then, organisms have reworked upper part of sediment, as is suggested by top core $1 \mathrm{st} \mathrm{m}$ measurements (MC-171: 320 $\pm 80)$. According to MC-166 and MC-167, sedimentation rate is between 13 and $15 \mathrm{~cm} / 100 \mathrm{yr}$.

\section{MC-100. Martigues fossil tree, France}

$35,000 \pm 4000$

caisson tree trunk found in $\mathrm{N}$ de Brtigues (43 $24^{\prime} \mathrm{N}$ Lat, $5^{\circ} 03^{\prime} \mathrm{E}$ Long) on Etang Ingénieur, Ponts et Chaussées france. Coll. and subm. 1966 by P. Couprie, $-18 \mathrm{~m}$ on gritty bedrock, sec of Leenhardt and. P. Couprie and P. Escudier (1964), p. 38. Comment (O. Leenhardt and M. R. Roux, 1967): date confirms former hypothesis that Martigues-Caronte thalweg results from stream scour of Arc R., during a marine regression of last Würm glaciation.

\section{North Ligurian Sea sediment series, France}

Sediment samples from 4 piston cores taken on continental slope between Antibes and Monaco, Alpes Maritimes. Coll. and subm. 1966 by M. Gennesseaux, Lab. de Geog. Phys. et Geol. Dynamique, Fac. des Sci., Paris (Gennesseaux and Thommeret, 1968).

\section{MC-95. N Ligurian Sea Sediment 1}

$$
8020 \pm 110
$$
Beaulieu $\left(43^{\circ} 41.8^{\prime} \mathrm{N}\right.$ Lat, $7^{\circ}$ core taken at depth $50 \mathrm{~m}$ in Baie de $>0.60 \mathrm{~mm}$, organic $>0.60 \mathrm{~mm}$, organic carbonate is $100 \%$, with only biodetrital fine sands from weed-field biocoenosis and adjacent rocky beds of Cap Ferrat.

\section{MC-96. N Ligurian Sea Sediment 2}

Sec. 430 to $440 \mathrm{~cm}$ in piston core $\mathbf{6 3 9 0}$ B.C. ning of continental slope $S E$ of core taken at $220 \mathrm{~m}$ depth, on beginLong). On grain-size fraction $>0.062$ Ferrat $\left(43^{\circ} 40.2^{\prime} \mathrm{N}\right.$ Lat, $7^{\circ} 20.5^{\prime} \mathrm{E}$ Comment (M.G.): no sign of climatic marian, organic carbonate is $100 \%$. out $5-\mathrm{m}$ sedimentary column. Accumulation rate is $50 \mathrm{~cm} / 1000 \mathrm{yr}$.
.

\section{MC-97. N Ligurian Sea Sediment $3 \quad 14,100 \pm 300$}

Sec. 90 to $100 \mathrm{~cm}$ in $1-\mathrm{m}$ piston core taken at 90 tinental shelf of Antibes $\left(43^{\circ} 36.5^{\prime} \mathrm{N}\right.$ Lat, $7^{\circ}$ (M.G.): as shell fragments (>1.25 mm) and Forant ( $>1.25 \mathrm{~mm})$ and Foraminifera are related to

\section{MC-98. N Ligurian Sea Sediment 4}

$27,400 \pm 100$ nental slope SE of Monaco (430 41.1' N Lat, $7^{\circ} 2355^{\prime} \mathrm{m}$ depth on conti(M.G.): assoc. of pelagic forams all through sedimentary column is typi- 
cal of climate cooler than present, indicating removal of top sediment, probably by gravitational sliding. Sample grain-size fraction $>0.125 \mathrm{~mm}$.

MC-99. N Ligurian Sea Sediment 5

$29,600 \pm 2600$

27,650 в.C.

Same core sec. sample as MC-98, grain-size fraction: 0.04 to $0.125 \mathrm{~mm}$. Comment (M.G.): MC-98 and MC-99 dates agree with end of Middle Würm, confirmed by pelagic fauna associations.

\section{Saint Jean Cap Ferrat Sediment series, France}

Surface sediment cautiously sampled by deep divers using manual coring to avoid any layer disturbance. Coll. in course of "Conshelf III Capt. J. Y. Cousteau's experiment," Oct. 1965 at $110 \mathrm{~m}$ depth in SE of Cap Ferrat, Alpes Maritimes (43 $40.3^{\prime} \mathrm{N}$ Lat, $7^{\circ} 19.6^{\prime} \mathrm{E}$ Long) and ca. $300 \mathrm{~m}$ from shore line. Subm. by Centre Scientifique de Monaco. Mean length of cores: $12 \mathrm{~cm}$. Two levels have been considered: the upper, 0 to $6 \mathrm{~cm}$, composed of madreporean debris, small mollusc shells and coarse shell fragments in clay filling. The lower, 6 to $12 \mathrm{~cm}$, is similar except madreporean debris is crushed in shelly matrix mixed with clay.

Section 0 to $6 \mathrm{~cm}$ in cores

\begin{tabular}{ll} 
& \multicolumn{1}{c}{ Section 0 to 6} \\
& \\
MC-133. & Madreporean fragments \\
MC-130. & Molluse shells \\
MC-132. & Vermetus shells \\
MC-131. & $\mathbf{0 . 2 5 0}<\mathbf{S}$ \\
MC-139. & $\mathbf{0 . 0 7 5}<\mathbf{S}<\mathbf{0 . 2 5 0}$ \\
MC-140. & $\mathbf{0 . 0 4 0}<\mathbf{S}<\mathbf{0 . 0 7 5}$ \\
MC-141. & silt $<\mathbf{0 . 0 4 0}$
\end{tabular}

$$
\begin{aligned}
& \text { Apparent age } \\
& \text { years } \\
&(\mathbf{1 0 8 . 6} \pm \mathbf{0 . 7} \% \text { modern }) \\
& \mathbf{7 8 0} \pm \mathbf{1 4 0} \\
& \mathbf{2 3 2 0} \pm \mathbf{1 7 5} \\
& \mathbf{3 6 0 0} \pm \mathbf{7 0} \\
& \mathbf{6 6 0 0} \pm \mathbf{1 0 0} \\
& \mathbf{1 0 , 5 8 0} \pm \mathbf{1 4 0} \\
& \mathbf{1 3 , 2 0 0} \pm \mathbf{2 0 0}
\end{aligned}
$$

Section 6 to $12 \mathrm{~cm}$ in cores

MC-134. Molluse shells

MC-136. Vermetus shells

MC-143. $\quad 0.750<S$

MC-135. $\quad 0.250<S<0.750$

MC-137. $0.075<$ S $<0.250$

MC-138. $\quad 0.040<S<0.075$

$$
\begin{aligned}
\mathbf{1 1 7 0} & \pm \mathbf{6 0} \\
\mathbf{2 7 0 0} & \pm \mathbf{8 0} \\
\mathbf{2 0 0 0} & \pm \mathbf{8 0} \\
\mathbf{2 3 5 0} & \pm \mathbf{8 0} \\
\mathbf{2 6 4 0} & \pm \mathbf{8 0} \\
\mathbf{1 0 , 8 0 0} & \pm \mathbf{2 0 0}
\end{aligned}
$$

$\mathrm{S}$ : sample grain-size fraction in $\mathrm{mm}$.

General Comment: measurements were made to estimate extent of suspected discrepancies between various sifted fractions or various biocoenosis sampled in top of sediment core taken near coast. Debris of sublittoral Madreporeans, which have $\mathrm{C}^{14}$ isotopic content closer to that of present $\mathrm{C}^{14}$ content of sea than mollusc fraction, tends to reduce apparent age of mixed debris in 6- to $12-\mathrm{cm}$ level. On the other hand, decay of old biogenic benches and erosion of such constituents as Vermetus shells 
contribute to apparent older age of sediment. Obviously dates on sifted fractions are meaningless for estimation of accumulation rates in surface sediments on continental slope (Thommeret and Thommeret, 1966).

\section{Central Mediterranean deep-sea sediment series}

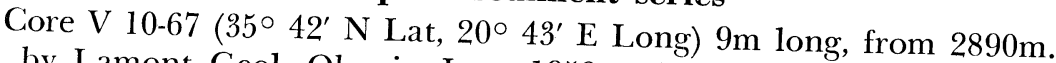
Coll. by Lamont Geol. Obs. in June 1958, subm. 1967 by Y. Herman, Dept. of Geol., Washington State Univ. All samples measured on mainly planktonic Foraminifera and Pteropoda tests with grain-size $>74 \mu$.

$$
\begin{array}{lll}
\text { MC-216. } & \text { V 10-67, } 68 \text { to } 81 \mathrm{~cm} & 19,200 \pm 450 \\
& & 17,250 \mathrm{B.C} . \\
\text { MC-217. } & \text { V } 10-67,96 \text { to } 109 \mathrm{~cm} & 23,900 \pm 800 \\
& & 21,950 \text { B.C. } \\
\text { MC-218. } & \text { V 10-67, } 268 \text { to } 277 \mathrm{~cm} & 35,000 \pm 4000
\end{array}
$$
ment (Y.H.): due to possibility that black layer sapropelitic mud. Comshould be considered maximum that reworked material was present, age

\section{MC-219. V 10-67, 330 to $339 \mathrm{~cm}$}

$28,200 \pm 1200$

Sample from organic-rich layer, sapropelitic mud.

MC-220. V 10-67, 383 to $395 \mathrm{~cm}$ 26,250 в.C. stade within Würm.

\section{Israel Mediterranean shelf sediment series}

Two cores from off Haifa and Akko, coll. and subm. 1966 by Y. Nir, Marine Geol. Div., Geol. Survey of Israel, Jerusalem.

\section{MC-183. Haifa, Israel}

$$
3920 \pm 120
$$

Piston core No $1561\left(920^{\circ} 54^{\prime \prime} 95^{\prime \prime}\right.$ depth ca. $100 \mathrm{~m}$; distance from shore, $16{ }^{\prime} \mathrm{km}$ Lat, $34^{\circ} 54^{\prime} \quad \mathrm{E}$ Long) water in core: 70 to $80 \mathrm{~cm}$.

\section{Akko, Israel}

Piston Core $1569\left(32^{\circ} 56^{\prime} \mathrm{N}\right.$ Lat, $35^{\circ} 00^{\prime} 30^{\prime \prime} \mathrm{E}$ Long) water depth $31 \mathrm{~m}$; distance from shore, $5.3 \mathrm{~km}$. Mostly silty clay with very low sand percentage; sand is composed mainly of macrofauna shells and Fora-
minifera. Grain-size fraction $>0.062 \mathrm{~mm}$.
MC-178. Akko, Israel, 0 to $10 \mathrm{~cm}$
$4460 \pm 100$
2510 s.c.
MC-179. Akko, Israel, 30 to $40 \mathrm{~cm}$
$3920 \pm 130$
1970 B.C.


$4430 \pm 130$

2480 B.C.

$4150 \pm 100$

2200 B.C.

$5480 \pm 100$

MC-182. Akko, Israel, 150 to $160 \mathrm{~cm}$
$\mathbf{3 5 3 0}$ B.c. General Comment: shallow depth of water and subsequent sion can be drawn about rate of sedimentation in area. (Y.N.): origin of of sediments in Israel Mediterranean shelf is from 4 main sources: a) floods of Nile R., b) local wadis from land (only in winter time), c) abrasion of sea shore cliffs, d) syngenetic dead fauna shells.

\section{Lebanon shore series}

Shells (Vermetus sp.) coll. and subm. 1966 by M. Fevret, Fac. des Lettres et Sciences Humaines, Aix, Bouches du Rhône, France and P. Sanlaville, Inst. de Geog. de Beyrouth, Lebanon. Would date some low levels of sea along Lebanon shore.

\section{MC-145. Ilôt du Palmier, Lebanon 1}

$3090 \pm 80$

1140 B.C.

Shells (Vermetus sp.) found ( $34^{\circ} 29^{\prime} \mathrm{N}$ Lat, $35^{\circ} 48^{\prime} \mathrm{E}$ Long) on flat surface covering whole islet at ca. +2.20 to $2.50 \mathrm{~m}$.

\section{MC-146. Ilôt du Palmier, Lebanon 2}

$$
1480 \pm 50
$$

\section{A.D. 470}

Shells (Vermetus sp.) found $\mathrm{S}$ of islet between 4 to $5 \mathrm{~m}$ from sea shore, on upper bench $(+80$ to $90 \mathrm{~cm})$.

\section{MC-147. Ile Bellène, Lebanon}

$$
2430 \pm 70
$$

480 B.C.

Bony breccia found on W surface of Ile Bellène $\left(35^{\circ} 47^{\prime} \mathrm{N}\right.$ Lat, $34^{\circ}$ $28^{\prime} \mathrm{E}$ Long), 10 to $20 \mathrm{~m}$ from sea, alt. +1.5 to $2 \mathrm{~m}$. Bones included in marine bioherm have been dated on mineral fraction.

MC-148. Ras el Taïr cave, Lebanon 1
Shells (Vermetus sp.) extracted from marine

$$
23,600 \pm 900
$$
near entrance to Ras el Taïr cave $\left(35^{\circ} 57^{\prime} \mathrm{N}\right.$ Lat, $35^{\circ} 36^{\prime} \mathrm{E}$ Long).

\section{MC-149. Ras el Taïr cave, Lebanon 2}

$$
26,300 \pm 1400
$$

Same species of Vermetus shells found 1m higher than MC-148, on ceiling of cave; bottom filled with conglomerate including Tyrrhenian Strombus fauna.

General Comment (M.F., P.S.): MC-145 and MC-146 corroborate continuous lowering of sea level during last 3 millennia. MC-148 and MC-149 agree with revised date some quaternarists assign to Tyrrhenian (Fevret, Picard, and Sanlaville, 1966). 


\section{A. France}

Abris de Saint Mitre series, Basses Alpes

Charcoal from hearths in archaeologic site formed by several rockshelters exposed to $\mathrm{E}$ in bottom of Saint Mitre ravine cutting through

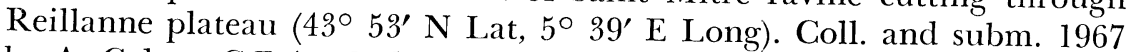
by A. Calvet, C.E.A., Cadarache, Bouches du Rhône, France.

\section{MC-201. Abris de Saint Mitre 1}

$4350 \pm 150$

Abri II, Layer 3, Chassean Neolithic occupation in which was found sharp arrow head of Lagosian type from Trets.

MC-203. Abris de Saint Mitre 2

$5150 \pm 200$

Abri III, Hearth 12/1 in upper Chassean layer.

\section{B.C.}

\section{MC-202. Abris de Saint Mitre 3}

Abri III, Hearth $12 / 2$ in lower Chassean layer, 4000 B.C. layer. Comment: results agree with stratigraphic sequence. Excavation is in process and more results will be reported later.

\section{Saint Martin du Touch series, Toulouse, Haute Garonne}

Charcoal from prehistoric and protohistoric dwellings $\left(\begin{array}{lll}42^{\circ} & 37^{\prime} \mathrm{N}\end{array}\right.$ Lat, $1^{\circ} 23^{\prime} \mathrm{E}$ Long) brought to light in course of excavations in W suburbs of Toulouse, close to ancient Roman amphitheatre. Coll. 1965 by G. Simonnet and subm. by L. Méroc, Dir. des Antiquités Préhistoriques, Toulouse, Haute Garonne.

MC-101. Saint Martin du Touch 1 $2250 \pm 170$

Charcoal A 35 No. 25.

MC-102. Saint Martin du Touch 2

$4500 \pm 200$

Charcoal A 36 No. 10.

2550 B.C.

MC-103. Saint Martin du Touch 3

Charcoal A 18 W No. 422.

$4580 \pm 120$

2630 B.C.

MC-104. Saint Martin du Touch 4

$5260 \pm 200$

Charcoal A 34 N No. 39 bis.

3310 B.C.

MC-105. Saint Martin du Touch 5

Charcoal A 34 S No. 266.

$4900 \pm 150$

2950 B.C.

MC-106. Saint Martin du Touch 6

$4900 \pm 200$

Charcoal A 38 SW No. 68. 


\section{MC-109. Saint Martin du Touch 7}

Charcoal A 61 A No. 24.

General Comment: MC-101 does not agree with expected date since deposit from which charcoal was found contains much older pottery of Halstatian period. Other dates confirm this important Neolithic settlement of "Tectosages," people of ancient Gaul who laid foundation of Toulouse more than 3000 yr B.c.

\section{B. Algeria}

Aïn Boucherit series, Saint Arnaud, Sétif

Archaeologic layer from Upper Capsian snail shell deposit, peculiar to Sétif dist. ( $36^{\circ} 13^{\prime} \mathrm{N}$ Lat, 5० $39^{\prime} \mathrm{E}$ Long). Coll. and subm. 1966 by G. Camps, Fac. des Lettres et Sciences Humaines, Alger.

\section{MC-209. Aïn Boucherit 1}

$6800 \pm 150$

Charcoal in layer 1.30 to $1.50 \mathrm{~m}$.

\section{MC-210. Aïn Boucherit 2}

4850 в.C.

Shells (Helix sp.) in layer 1.30 to $1.50 \mathrm{~m}$.

General Comment (G.C.): samples from lower level of layers indicating rather late settlement. Shells taken few mi. from this field, in deposits of Medjez II (cf. MC-213, MC-214, and MC-151, Gif-462, Gif-885 to 889) indicate occupancy in area since 6500 в.c. MC-209 and MC-210 also show that snail shells can be used for dating when charcoal is lacking in these types of archaeologic deposits.

\section{Medjez II series, Saint Arnaud, Sétif}

Large snail shell deposit (escargotière) of El Eulma $\left(36^{\circ} 08^{\prime} \mathrm{N}\right.$ Lat, $5^{\circ} 40^{\prime} \mathrm{E}$ Long) especially interesting for industry and cultural artifacts: sculpted and carved stones, human skulls converted into cups. Human skeleton of proto-Mediterranean type has been extracted from deposit. Coll. 1963 and 1967; subm. 1967 by G. Camps.

\section{MC-151. Medjez II 1}

$$
6500 \pm 100
$$

Charcoal coll. 1963 within $1 \mathrm{~m}$ depth in archaeologic ashy layer containing large quantities of snail shells. Comment (G.C.): agrees with other dating on charcoal sample from same layer (Gif-462, 4670 B.C.).

MC-213. Medjez II 2

$7860 \pm 120$

Charcoal coll. 1967 in layer 1 to $1.40 \mathrm{~m}$ deep.

MC-214. Medjez II 3 $\mathbf{5 9 1 0 ~ B . c . ~}$

Charcoal coll. 1967 in layer 1.80 to $1.90 \mathrm{~m}$ deep. 
General Comment (G.C.): MC-213 and MC-214 illustrate irregular chronology of deposition. It may be explained by nature of accumulated deposit: loose piles of snails that easily collapse. Medjez II facies is recent and is very little in advance of Neolithic. These datings (Gif-462, Gif885 to 889 , MC-151, MC-213 and MC-214) indicate continuation of Upper Capsian in Sétif area (6500 to 4500 B.C.) (Camps, 1966).

\section{Koudiat Kifen Lahda series, Aïn M'Lila, Constantine}

In dist. of Aïn M'Lila (E Algeria) site (36 $02^{\circ} \mathrm{N}$ Lat, $6^{\circ} 30^{\prime} \mathrm{E}$ Long) contains 2 types of superposed Epipalaeolithic industries. Coll. and subm. 1967 by G. Camps.

\section{MC-206. Koudiat Kifen Lahda 1}

$8050 \pm 150$

Charcoal from upper layer of snail shell deposit.

\section{MC-207. Koudiat Kifen Lahda 2}

6100 B.c.

Iayer assolithic micro-industry. Layer also dated by Gif (6570 B.c., Gif-879).

General Comment (G.C.): site interest is to bring to light an ultramicrolithic (called elassolithic) industry in E Algeria, prior to Upper Capsian, in stratigraphic position similar to one already known of Columnata (cf. MC-211, 6190 в.C.).

Charcoal from open air camp $\left(30^{\circ} 10^{\prime} \mathrm{N}\right.$ Lat, $6^{\circ} 30^{\prime}$ E Long) wic.

Neolithic Neolithic remains of Capsian tradition. Comment (G.C.): date appears too recent and may be due to external contamination, though sample has been processed and measured twice with same result; nevertheless, in E Algeria Neolithic of Capsian tradition began rather late and possibly lasted until such a recent date; only in Sahara such low dates are known (Tamanrasset II: 1380 в.c. Gif-357, Zmerlet Barka: 1000 в.c., Gif, unpubl.).

\section{Columnata series, Waldeck Rousseau, Tiaret}

Columnata site $\left(35^{\circ} 27^{\prime} \mathrm{N}\right.$ Lat, $1^{\circ} 36^{\prime} \mathrm{E}$ Long) is dismantled rockshelter established at base of cliff of helvetian sandstone. Settlement studied since 1937 and has delivered innumerable paleontologic remains, lithic tools, polished bone artifacts, and abundant potsherds in numerous stratigraphic layers. Coll. and subm. 1967 by G. Camps.

\section{MC-156. Columnata 1}

$5850 \pm 100$

(c 10) charcoal, coll. 1959 in Neolithic layer with typical pottery and tools. Comment (G.C.): Neolithic impregnation in layer ascribed to Upper Capsian has been dated 3300 в.c. (Gif-307).

MC-153. Columnata 2

Col. 130-160 (c 2) charcoal coll. 1955.

$6800 \pm 100$

4850 в.c. 
MC-154. Columnata 3

5350 B.C.

H 15 (c 5) carbonized substance appearing as charcoal. Coll. 1957. Comment: sample was largely soluble in both $2 \%$ diluted $\mathrm{HCl}$ and $\mathrm{NaOH}$ pretreatment solutions. Significant difference in age (900 yr older) was found in dissolved $\mathrm{NaOH}$ washing solution. Lab contamination cannot be accounted for. No explanation found.

\section{MC-155. Columnata 4}

$8280 \pm 200$

H 39 (c 6) charcoal coll. 1957.

6330 в.c.

\section{MC-211. Columnata 5}

$8140 \pm 130$

6190 B.C.

Col. 15 (c 5) charcoal coll. 1957 in ash layer under small shelter where micro-industry was free from irrelevant mixing.

General Comment (G.C.): MC-156 agrees with Neolithic level. MC-153, MC-154, MC-155, and MC-211 would date Epipalaeolithic layers corresponding to a transition phase between Iberomaurusian and Upper Capsian, characterized by very microlithic tools. MC-154 and MC-155 pertain to burials from basis of layers. Stratigraphic sequence of deposit is such: Neolithic from 3900 в.C., Upper Capsian between 4900 and 4400 в.c., micro-industry or Columnatian from 6300 to 5400 B.C., Iberomaurusian below 8000 в.c. Sample dates agree with dates already known of Upper Capsian (cf. MC-151) and Iberomaurusian (10,000 to 8000 B.C. in Taforalt) and contribute to idea that micro-industry was contemporary with some facies types of E Upper Capsian (facies of R'Fana, 5500 B.C.) (Cadenat, 1958, 1966).

MC-150. Hassi Mouilah, Ouargla, Oasis

$8600 \pm 150$

6650 B.C.

Site with stratified layers in $\mathrm{W}$ of Ouargla (Oasis district) $\left(32^{\circ} 8^{\prime} \mathrm{N}\right.$ Lat, $5^{\circ} 7^{\prime} \mathrm{E}$ Long). Charcoal coll. 1966 at $1.50 \mathrm{~m}$ under Neolithic layer already dated 3320 B.C. (Gif-438). Comment (G.C.): Epipalaeolithic industry with lamellas superimposed by Neolithic of Capsian tradition. Date agrees with expectations. 1st dated site comprising industry with lamellas.

MC-152. EI Biod, Fort Flatters, Oasis

$7300 \pm 200$

$\mathbf{5 3 5 0}$ B.C.

Large Neolithic site in place called El Bayed $\left(28^{\circ} 30^{\prime} \mathrm{N}\right.$ Lat, $5^{\circ} 58^{\prime}$ E Long) between Fort Flatters and El Golea. Charcoal coll. 1966 in very thin archaeologic layer, subm. by G. Camps. Comment (G.G.): date appears somewhat high when compared with Neolithic tools of same layer. However site does not relate to same facies as Hassi Mouilah Neolithic (MC-150) which is richer in ceramics. Those are scarce in El Biod. 


\section{MC-212. Amekni, Tamanrasset}

$8670 \pm 150$

6720 B.c.

Shelter $2\left(22^{\circ} 55^{\prime} \mathrm{N}\right.$ Lat, $5^{\circ} 15^{\prime} \mathrm{E}$ Long). Charcoal from hearths located under fallen shelters, middle layer: 50 to $80 \mathrm{~cm}$. Coll. 1965 and subm. by G. Camps. Comment (G.C.): Neolithic site of Sudanese tradition in Hoggar desert. Date is very old as sample comes from sandy layer immediately below habitat, but confirms former sample dated 6100 B.c. (UW-87). However, date for this level which contains ceramics appears too old to be definitively retained, unless it is supposed that Central and S Sahara were focus of early neolithization at about same time as Middle East.

\section{Madagascar}

\section{Aepyornis egg-shell series}

Egg-shell fragments from Aepyornis maximus found in S of Madagascar. Coll. and subm. 1967 by L. Marden, Natl. Geog. Soc., Washington, D. C.

\section{MC-198. Tulear}

$4600 \pm 100$

Belalanda site $\left(23^{\circ} 20^{\prime} \mathrm{S} \mathrm{Lat,} 43\right.$ layers of shell yield same results.

\section{MC-199. Ampomolora site}

Near Ambovombe (25 $10^{\prime} \mathrm{S}$ Lat, $46^{\circ} 00^{\prime} \mathrm{E}$ Long).

MC-200. Beroroha site (Ambovombe) 3650 B.c.

General Comment: all samples processed on carbonate fraction. 110 B.c. agree well with expected dates (Marden, 1966).

\section{MISCELLANEOUS SAMPLES}

\section{Atmospheric Radiocarbon Activity series, Monaco}

This series of $\mathrm{C}^{14}$ content measured in atmospheric $\mathrm{CO}_{2}$ quarterly coll. on roof of Mus. Océanog. Monaco (43 $43^{\prime} \mathrm{N}$ Lat, $7^{\circ} 25^{\prime} \mathrm{E}$ Long), alt. $80 \mathrm{~m}$, is continuation of list previously publ. in Radiocarbon, 1966, v. 8 , p. $286-291$.

\begin{tabular}{|c|c|c|c|}
\hline MC-78. & Nov. & 1965 & $\begin{array}{c}\delta \mathbf{C}^{14 \%} / 0 \\
+\mathbf{7 2 9} \pm \mathbf{2 0}\end{array}$ \\
\hline MC-79. & March & 1966 & $+645 \pm 20$ \\
\hline MC-157. & May & 1966 & $+642 \pm 20$ \\
\hline MC-158. & Aug. & 1966 & $+650 \pm 15$ \\
\hline MC-160. & Feb. & 1967 & $+612 \pm 15$ \\
\hline MC-161. & May & 1967 & $+610 \pm 15$ \\
\hline MC-162. & Aug. & 1967 & $+664 \pm 20$ \\
\hline MC-163. & Nov. & 1967 & $+695 \pm 15$ \\
\hline $\begin{array}{l}\text { MC-259. } \\
\text { MC-260. }\end{array}$ & Feb. & 1968 & $+603 \pm 20$ \\
\hline MC-260. & May & 1968 & $+590 \pm 20$ \\
\hline
\end{tabular}


Comment: Variations in $\mathrm{C}^{14}$ activity are similar to those encountered in other labs at same periods (Nydal, 1966; Radiocarbon, 1967, v. 9, p. 246256; 387-438; 477-504; 471-476).

\section{Contemporary sea organisms series}

\section{MC-128. Modern organisms 1$$
\delta \mathbf{C}^{14} / c_{c}+\mathbf{8 4} \pm \mathbf{1 0}
$$

Macro-planktonic crustaceans (Meganectiphanes norvegicus), coll. alive Feb. 1966 in vicinity of Monaco.

\section{MC-222. Modern organisms 2}

$$
\delta \mathbf{C}^{140} / c_{c}-\mathbf{6 2} \pm \mathbf{8}
$$

Shells (Lithophaga Lithophaga) coll. alive July 1967, in sub-littoral zone near Cap Ferrat, Alpes Maritimes. Shells were extracted by breaking calcareous rocks in which they live.

MC-223. Modern organisms 3

$\delta \mathbf{C}^{14 \%} \%+\mathbf{1 2 3} \pm \mathbf{1 0}$

Calcified fragments of bryozoan colonies. Coll. alive 1967 by diving $(-20 \mathrm{~m})$ at Saint Jean Cap Ferrat, Alpes Maritimes.

\section{Seawater series}

Samples (117 L) of sea water coll. $20 \mathrm{~km} \mathrm{~S}$ Monaco, regularly monitored for $\mathrm{C}^{14}$ content of dissolved carbonates and bicarbonates, in order to compare with apparent age of modern organisms which live in same seawater.

\section{MC-175. Deep seawater 1}

$\mathbf{C}^{14} \%+\mathbf{2 0} \pm \mathbf{1 0}$

Seawater coll. March 1967, 2000m deep.

MC-177. Deep seawater 2

$$
\mathrm{C}^{14} \%+27 \pm \mathbf{1 0}
$$

Seawater coll. July 1967, 2000m deep.

MC-176. Surface seawater 1

$\mathrm{C}^{14} \%+\mathbf{5 0} \pm \mathbf{1 0}$

Surface seawater coll. March 1967.

\section{REFERENCES}

Date lists:

$\begin{array}{ll}\text { Copenhagen VIII } & \begin{array}{l}\text { Tauber, 1967 } \\ \text { Gif II }\end{array} \\ \text { Delibrias, Guillier, and Labeyrie, } 1966 \\ \text { Thomaco I } & \text { Thommeret and Rapaire, 1964 } \\ \text { Monaco II } & \text { Coppens, Durand, and Guillet, 1968 } \\ \text { Nancy I } & \text { Delibrias, Guillier, and Labeyrie, 1964 } \\ \text { Saclay I } & \text { Engstrand, 1967 } \\ \text { Stockholm VII } & \text { Berger and Libby, 1967 } \\ \text { UCLA VI } & \text { Stenberg and Olsson, 1967 } \\ \text { Uppsala VIII } & \end{array}$

Cadenat, P., 1958, Atlas préhistorique: Libyca, t. VI, p. 27.

1966, Vues nouvelles sur les industries de Columnata: Libyca, t. XIV, p. 207.

Camps-Fabrer, H., 1966, Matière et Art mobilier dans la préhistoire nord-africaine et saharienne; in: Mémoires du Centre de Recherches Anthropologiques Préhistoriques et Ethnographiques: Paris, Arts et Métiers Graphiques, 573 p.

Couprie, P. and Escudier, P., 1964, Le nouveau pont de Martigues: Travaux, no. 350, p. 33-42. 
Fevret, M., Picard, J., and Sanlaville, P., 1966, Sur la possibilité de datation de niveaux marins quaternaires par les Vermets: Acad. sci. [Paris]. Comptes rendus, t. 264,
p. 1407-1409.

Fevret, M. and Sanlaville, P., 1966, L'utilisation des Vermets dans la détermination des anciens niveaux marins: Méditerranée, no. 4, p. 357-364.

Gennesseaux, M. and Thommeret, Y., 1968, Estimation du taux de sédimentation sur la pente continentale niçoise: Rapports et Procès verbaux des Réunions de la CIESM, in press.

Leenhardt, O. and Roux, M. R., 1967, Morphologie du substratum de l'étang de Berre: Soc. géol. France Bull., v. 9, no. 7, p. 88-92.

Marden, L., 1967, Madagascar, Island at the end of the earth: Nat. Geog. Mag., v. 132, p. 443.

Nydal, R., 1966, Variation in $\mathbf{C}^{14}$ concentration in the atmosphere during the last several years: Tellus, v. 18, p. 271-279.

Thommeret, J. and Thommeret, Y., 1967, Répartition des teneurs en carbone 14 naturel dans divers constituants de la biophase d'un sédiment superficiel de la Méditerranée occidentale: Cahiers Océanographiques, v. XIX, p. 495-504.

Thommeret, J. et al., 1968, Ensemble de comptage et d'impression automatique utilisé pour la datation par la méthode du carbone 14: Lab. rep., in press. 